\title{
A Review on the Kenaf/Glass Hybrid Composites with Limitations on Mechanical and Low Velocity Impact Properties
}

\author{
Seri Nur Zumaimi Ahmad Nadzri ${ }^{1}$, Mohamed Thariq Hameed Sultan ${ }^{1,2,3, *}$, \\ Ain Umaira Md Shah ${ }^{1,2} \mathbb{E}$, Syafiqah Nur Azrie Safri ${ }^{1,2}{ }^{-}$and Adi Azriff Basri ${ }^{2}$ \\ 1 Laboratory of Biocomposite Technology, Institute of Tropical Forestry and Forest Products (INTROP), \\ UPM Serdang 43400, Selangor Darul Ehsan, Malaysia; snzumaimi@gmail.com or \\ seri_nurzumaimi@yahoo.com (S.N.Z.A.N.); ainumaira91@gmail.com (A.U.M.S.); \\ snasafri@gmail.com (S.N.A.S.) \\ 2 Department of Aerospace Engineering, Faculty of Engineering, Universiti Putra Malaysia, \\ UPM Serdang 43400, Selangor Darul Ehsan, Malaysia; adiazriff@upm.edu.my \\ 3 Aerospace Malaysia Innovation Centre (944751-A), Prime Minister's Department, MIGHT Partnership Hub, \\ Jalan Impact, Cyberjaya 63000, Selangor Darul Ehsan, Malaysia \\ * Correspondence: thariq@upm.edu.my
}

Received: 5 February 2020; Accepted: 24 March 2020; Published: 4 June 2020

check for updates

\begin{abstract}
Environmental awareness and trends to develop sustainable resources have directed much research attention towards kenaf fibre as an alternative reinforcement in composite manufacturing. Numerous studies have been conducted on kenaf and its hybrid composites. Most studies were conducted on kenaf/glass hybrid composites compared to other kenaf/synthetic hybrid composites. Similar with other materials, mechanical properties were the fundamental knowledge identified by the researcher. Limited studies conducted on other properties have restricted the use of kenaf composites to non-structural applications. To extend the potential of kenaf composites to automotive exterior or other critical applications, studies on impact properties can be a valuable contribution in the material field. This review discusses the mechanical and low velocity impact properties of kenaf/glass hybrid composites reported previously. Percentage loading of fibre, the angle of orientation in woven fibres and the chemical treatment applied to the fibre before compounding are the three major parameters that affect the mechanical and impact properties of the composites. This review provides insights into the mechanical and impact properties of kenaf/glass hybrid composites for future research.
\end{abstract}

Keywords: kenaf fibre; glass fibre; hybrid composites; low velocity impact

\section{Introduction}

The usage of natural fibres such as kenaf in automotive applications has the potential advantage of reducing the weight of the vehicle which helps to minimise the fuel consumption, thus reducing the emission of harmful gases [1,2]. However, due to several drawbacks such as strength of natural fibres, the application of these materials was limited to interior parts of vehicles. In expanding the potential applications of natural fibre composites to the exterior parts, the use of synthetic fibre as a hybrid material had been the interest of researchers around the world $[3,4]$. Pertaining to the chances of sudden impact to the exterior parts of vehicles, low velocity impact analysis is another vital aspect that needs to be addressed besides the main mechanical properties $[5,6]$. Therefore, this review was conducted to give an overview of the two main properties of kenaf, glass and their hybrid composites, which were mechanical and low velocity impact properties. Kenaf and glass fibre composites were seen to have big potential in various applications based on numerous studies reported to date. 
The synthetic fibre such as glass fibre was found to enhance the mechanical properties of the composite [7]. Embedding woven E-glass as the outermost layer of three plied composites, also containing kenaf and jute, was reported to increase the tensile strength by more than $50 \%$ [8]. In the previous research, the tensile strength of bamboo/glass reinforcing polyester hybrid composite was 80.56 MPa compared to the tensile strength of bamboo reinforced polyester composite and bamboo/jute reinforced polyester hybrid composites, recorded as 46.67 and $60.32 \mathrm{MPa}$, respectively [9]. As reported in a previous study, the hybridization of hemp and glass composite presented the increasing trend of flexural strength changing from 97.5 to $101 \mathrm{MPa}$ as the glass content in the composite increased from $0 \%$ to $15 \%$ [10].

Reducing the percentage of glass fibre in glass/polypropylene (PP) composites from $60 \%$ to $30 \%$ by replacing the reduced percentage with $30 \%$ twill woven bamboo fibres decreased the Charpy impact strength by less than $50 \%$. However, in comparison with non-hybrid bamboo/PP composites, the glass/bamboo hybrid composites showed higher a Charpy impact strength, of $1129 \mathrm{~J} / \mathrm{m}$, compared to $530.9 \mathrm{~J} / \mathrm{m}$ for the non-hybrid [11]. A composite with hybrid long fibres of both sugar palm and glass fibre, with a random orientation and 30:70 fibre ratio, respectively, in an epoxy matrix, showed its ability to withstand an impact energy up to $15 \mathrm{~J}$ in drop weight impact testing [12]. Various natural fibres have been used to be hybridised with glass fibres in an attempt to reduce the dependency on synthetic materials. On the other hand, the inclusion of glass fibre broadens the potential use of natural fibres in different applications.

This paper presents a short review on the mechanical and low velocity impact properties of kenaf/glass hybrid composites, to provide a reference for filling the gap in the respective research area. The aim is to enhance the potential of kenaf/glass hybrid composites to be used in automotive applications, based on their strength and impact properties.

\section{Kenaf Plant}

Kenaf plant, scientifically registered as Hibiscus cannabinus L., belongs to the family of Malvaceae. This herbaceous dicotyledonous plant grows during the warm season, similarly to okra and cotton plants, which belong to the same family of Malvaceae $[13,14]$. Table 1 shows the taxonomy of the kenaf plant.

Table 1. Kenaf plant's taxonomy.

\begin{tabular}{cc}
\hline Kingdom & Plantae \\
\hline Class & Magnoliopsida \\
Order & Malvales \\
Family & Malvaceae \\
Genus & Hibiscus \\
Species & Hibiscus cannabinus L. \\
\hline
\end{tabular}

Kenaf plant was introduced in the 1970s in Malaysia as an industrial crop in Kelantan, Pahang and Terengganu [15]. Then, kenaf plantations have been identified as an alternative to tobacco plantations [16]. Kenaf plant became popular in the 1990s, when it turned out to be an alternative resource for composite fabrications, such as in particle board, medium-density fibre board (MDF), wood plastic composites (WPC) and many more applications [17]. Besides being one of the alternative raw materials for replacing wood fibre in the pulp and paper industries, kenaf plant is also traditionally used to make ropes, canvas, and sacks [18].

\section{Extraction of Kenaf Fibres}

In engineering applications, specifically in the composites field, kenaf fibres need to be extracted from the respective parts of the kenaf plant. It has been reported that approximately $40 \%$ of the kenaf plant stem can be transformed into fibres. This high percentage makes kenaf economically comparable 
to other plants, such as jute, hemp, and flax [13]. The short growing cycle of the kenaf plant, in the range of 150 to 180 days, and its low water requirement, make it more suitable to be used in composites and other applications $[19,20]$. Figure 1 shows the illustration of bast fibre, which is the outermost tissue layer of the kenaf stem, as well as the core and pith, which are located in the centre of the kenaf stem $[21,22]$.

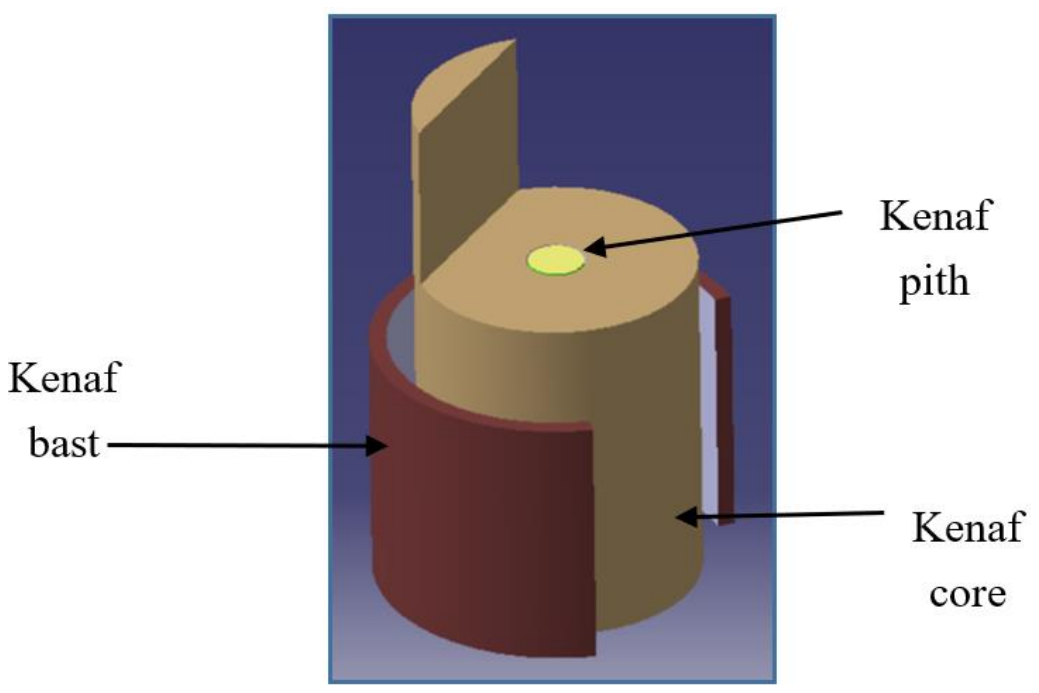

Figure 1. The illustration of kenaf stem.

The process of extracting plant fibres is also known as the retting or degumming process. There are a few retting methods applied to plant fibres reported to date, such as dew retting, water retting, enzymatic retting, chemical retting and mechanical retting [23]. Among them, the water, chemical, mechanical and enzymatic retting are the most commonly practiced processes in extracting kenaf fibres, as shown in Figure 2.

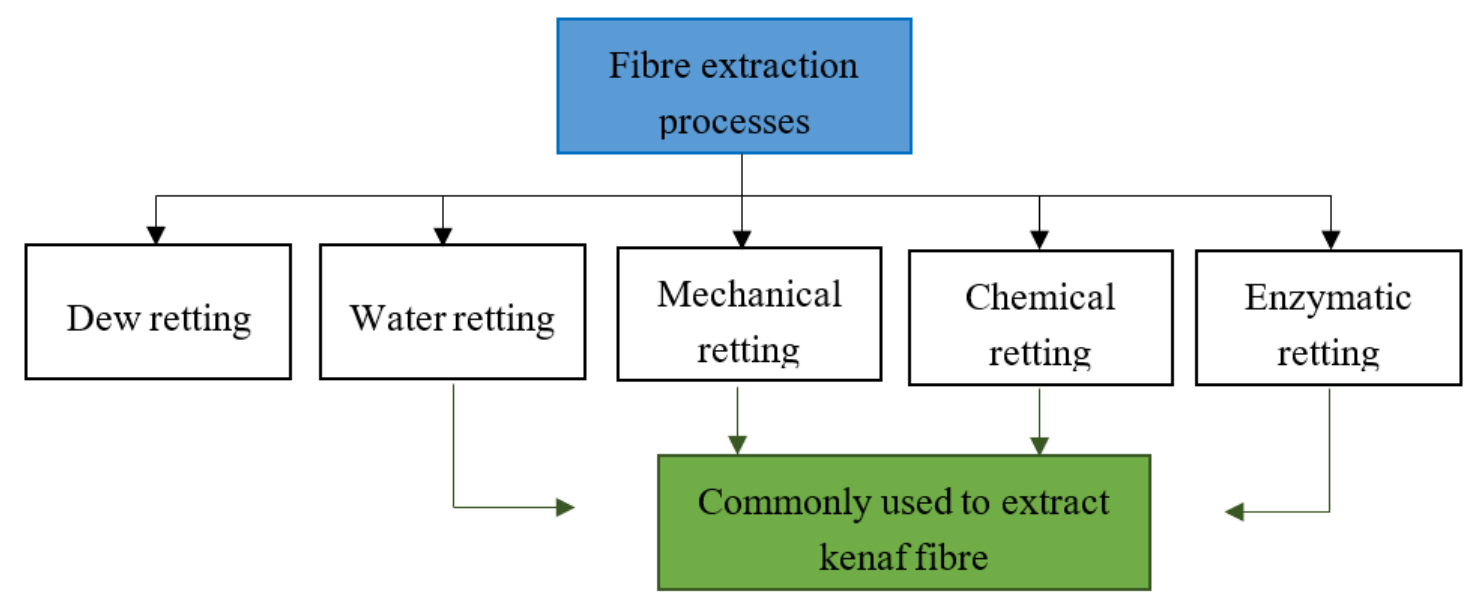

Figure 2. Different retting processes in extracting plant fibre.

Compared to mechanical and chemical retting, water retting takes a longer time to complete the process, which is about 22 days, including washing, drying and combing the fibre. This method begins by submerging the kenaf plant into water, such as in a pond, river or tank. Microbial actions will separate the kenaf fibres within the pith (Figure 1). This process, however, will lead to minor water pollution and produce a strong odour because of anaerobic bacterial fermentation $[24,25]$. The water retting process will be continued by washing the fibre with clean water to remove unwanted substances. The cleaned fibres will be oven dried at $60^{\circ} \mathrm{C}$ for $24 \mathrm{~h}$ until the fibre achieves constant weight [26]. 
A traditional method, such as air drying, can be used, depending on the surrounding humidity [27]. The combing process is carried out to disentangle the fibre, and at the same time to further extract single fibres from fibre bundles [28].

Mechanical retting, also called decortication, is the process of isolating the bast and the pith (Figure 1) using a decorticator. This method is easier, cheaper, and faster, compared to the other retting methods. Kenaf stalk will be immersed into water for at least 5 days before separating the fibre through the decorticating process [29]. Commonly used decorticating processes involve hammer milling and roller milling. Hammer milling is the process of beating the kenaf stem until the bast and core are separated. The small fibre obtained after the hammering process will be passed through the meshes inside the hammer milling machine. The roller milling machine will roll and crush the kenaf stalk, producing minimal damage to the fibre. Using this machine, longer fibre is achieved. The process of extracting fibre continues by washing, drying, and combing, similarly to the procedures in the water retting process, as explained earlier $[25,29]$. Figure 3 illustrates the fibre decortication process applied to extract kenaf fibre.

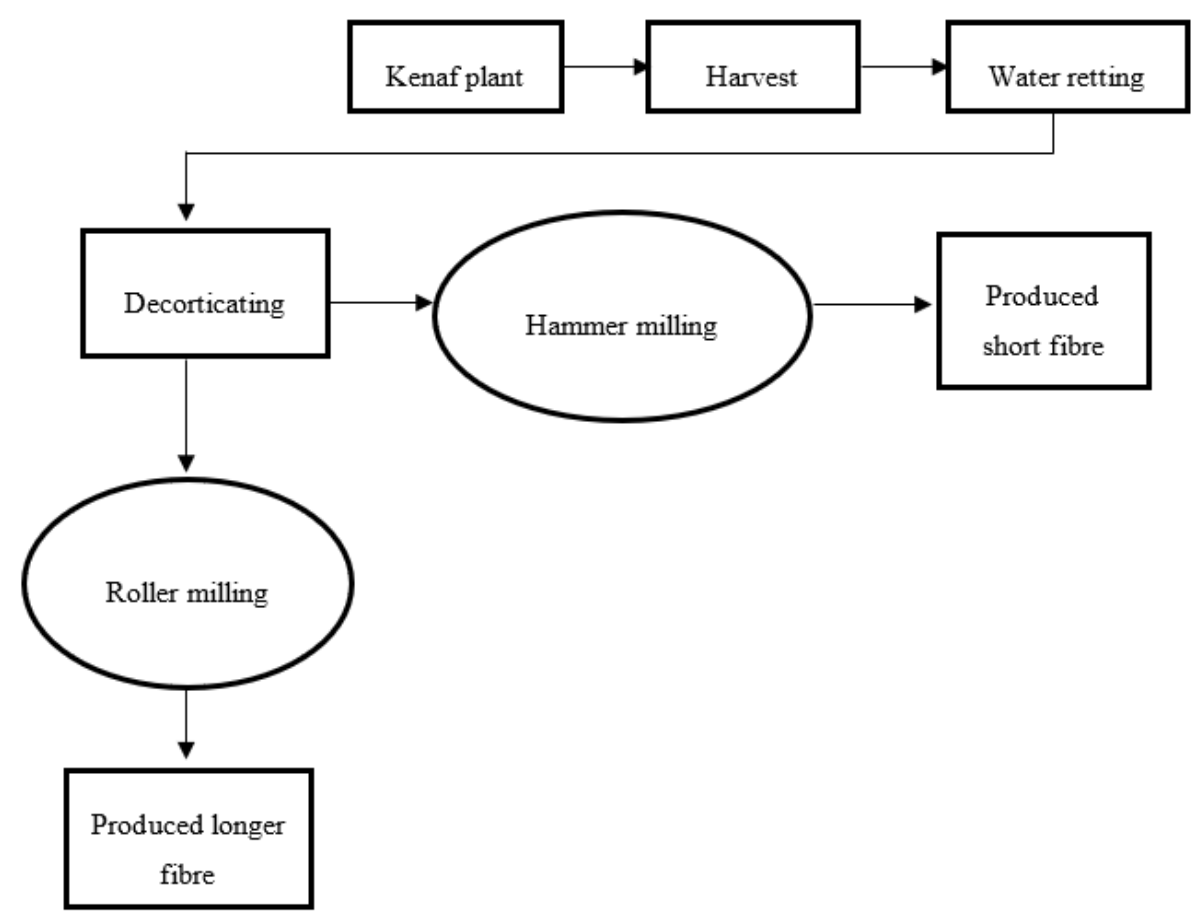

Figure 3. Fibre decortication process.

Physical retting, through steam explosion, is performed on the plant stalk before applying chemicals to soften the fibres. This process is eco-friendly and requires a shorter time to extract the fibres. Steam explosion is carried out at $0.5 \mathrm{MPa}$ for $15 \mathrm{~min}$, followed by alkali-oxygen treatment. These parameters have been suggested as the optimum pressure and time, respectively, to remove pectin, hemicellulose and lignin [24,30].

Chemical retting is the process where alkali hydrolysis takes place. The chemicals that are normally used are sodium hydroxide $(\mathrm{NaOH})$, sodium benzoate $\left(\mathrm{C}_{7} \mathrm{H}_{5} \mathrm{NaO}_{2}\right)$, and hydrogen peroxide $\left(\mathrm{H}_{2} \mathrm{O}_{2}\right)$. Smooth and long consistent fibre can be produced through this process in a short period of time. It has been suggested that these chemicals should be used in concentrations below $1 \%$, as a more concentrated alkaline solution could lead to the degradation of the tensile strength [24].

Enzymatic retting is based on a similar concept to that of water retting, which uses bacteria that produce pectic enzyme to extract the fibre by dissolving pectin. As biotechnology has advanced, this enzyme can be now produced in the laboratory and is commercially available. Enzymatic retting can be controlled, is efficient and most importantly environmentally friendly [31]. A suitable 
temperature range between 40 and $50^{\circ} \mathrm{C}$ has been established based on the most favorable working conditions for the enzyme [26,32]. However, this process involves higher costs, compared to water retting. The later washing, drying and combing processes are all similar to the procedure described for other types of retting.

\section{Glass Fibre}

Glass fibre is a commonly used synthetic fibre made from silicates, soda, clay, limestone, boric acid and various metallic oxides. All these constituents will undergo a heating process and will be refined in the narrow chamber [33]. Glass fibre is classified into several types, based on its main properties, and is denoted with letters C, D, E and S. C-glass fibre can be used in an acidic environment because it has the ability to resist corrosion. D-glass fibre has a low dielectric constant and it is commonly used in electrical applications. E-glass fibre is known as electrical glass, which is very good for electrical insulation. S-glass is a high strength glass fibre. It not only has high strength and stiffness, but also can be used in extreme conditions, such as in extreme temperatures or corrosive environments [34]. Table 2 shows the mechanical properties of different types of glass fibres.

Table 2. Mechanical properties of glass fibre types C, D, E and S.

\begin{tabular}{cccccc}
\hline & C-Glass & D-Glass & E-Glass & S-Glass & Ref. \\
\hline Density $\left(\mathrm{g} / \mathrm{cm}^{3}\right)$ & 2.56 & 2.11 & 2.54 & 2.53 & \\
Tensile strength (MPa) & 3300 & 2500 & 3400 & 4600 & \\
Young's Modulus (MPa) & 69 & 55 & 72 & 89 & {$[34]$} \\
Elongation (\%) & 4.8 & 4.5 & 4.7 & 5.2 & \\
\hline
\end{tabular}

\section{Mechanical Properties of Kenaf/Glass Hybrid Composites}

Kenaf fibre has low density and good mechanical properties. Replacing part of synthetic fibre such as glass fibre with kenaf fibre in a composite will reduce the structure's weight and cost, and will be more environmentally friendly. The mechanical properties of kenaf and glass fibres are illustrated in Table 3.

Table 3. General mechanical properties of kenaf fibre and glass fibre.

\begin{tabular}{ccc}
\hline & Kenaf & Glass \\
\hline Density $\left(\mathrm{g} / \mathrm{m}^{3}\right)$ & 1.45 & 2.55 \\
Tensile strength $(\mathrm{MPa})$ & 930 & 3400 \\
Elastic modulus $(\mathrm{GPa})$ & 53 & 71 \\
Elongation at break $(\%)$ & 1.6 & 3.4 \\
References & {$[18,35]$} & {$[36,37]$} \\
\hline
\end{tabular}

Kenaf/glass hybrid composites with $90^{\circ}$ orientations was reported to achieve higher tensile strength compared to $0^{\circ}$ orientations with values of 69.86 and $49.27 \mathrm{MPa}$, respectively. The load applied in the direction parallel to the fibre contributed to the higher strength of $90^{\circ}$ orientations kenaf/glass hybrid composites compared to the load applied perpendicular to the orientation of fibre [38]. The contribution of synthetic fibre, which is known for its strength and stiffness, was seen in the increment of tensile and flexural strength of kenaf/glass hybrid composites to 65.29 and $115.71 \mathrm{MPa}$ compared to non-hybrid kenaf composites with 49.48 and 77.63 MPa, respectively [39].

Table 4 summarises the findings reported from studies on the mechanical properties of kenaf/glass fibre hybrid composites. 
Table 4. Reported research on mechanical properties of kenaf/glass fibre hybrid composites.

\begin{tabular}{cccc}
\hline Materials & \multicolumn{2}{c}{ Mechanical Properties } & \multirow{2}{*}{ Ref. } \\
\cline { 2 - 3 } & Tensile & Flexural & \\
\hline $90^{\circ}$ fibre orientation of kenaf + chopped strand glass fibre reinforced epoxy & $69.86 \mathrm{MPa}$ & $162.566 \mathrm{MPa}$ & {$[38]$} \\
kenaf fibre yarn + woven glass fibre reinforced epoxy & $65.29 \mathrm{MPa}$ & $115.71 \mathrm{MPa}$ & {$[39]$} \\
Woven kenaf fibre + glass fibre mat reinforced unsaturated polyester & $85.49 \mathrm{MPa}$ & $124.07 \mathrm{MPa}$ & {$[40]$} \\
\hline
\end{tabular}

Chemical treatment using alkaline solution is the most commonly used due to its low cost and high effectiveness [41]. Kenaf fibre treated with $9 \% \mathrm{NaOH}$ solution for $12 \mathrm{~h}$ presented the highest flexural strength of $93.3 \mathrm{MPa}$ compared to $3 \% \mathrm{NaOH}$ and untreated kenaf fibre which were 63.2 and $25.1 \mathrm{MPa}$, respectively. The adequate surface roughness of kenaf fibre treated with $9 \% \mathrm{NaOH}$ improved the fibre matrix bonding, while a $3 \% \mathrm{NaOH}$ concentration was not sufficient to remove the impurities on the surface of fibre [42]. In a different study, maintaining the percentage of kenaf fibre loading at $25 \%$ in two types of polymer matrix, epoxy and polyester, results in higher tensile strength for the epoxy-based composites with a value of $93.59 \mathrm{MPa}$ compared to polyester-based composites at $86.54 \mathrm{MPa}$ [43]. The fact that epoxy resin has better properties (such as high strength and low shrinkage) compared to polyester resin which is poor in adhesive and high cure shrinkage, indirectly contributes to the overall strength of composites [44].

In a research project that investigated the mechanical properties of different amounts of kenaf (K) layers in glass $(\mathrm{G})$ fibre composites, one layer of kenaf as the core between three layers of glass fibre each at the top and bottom of the sandwich structure $(3 \mathrm{G} / \mathrm{K} / 3 \mathrm{G})$ presented the highest tensile strength compared to $3 \mathrm{G} / 2 \mathrm{~K} / 3 \mathrm{G}$ and $3 \mathrm{G} / 3 \mathrm{~K} / 3 \mathrm{G}$, which had two and three layers of kenaf as the core in the same sequences. The study suggested that the increment in the number of kenaf layers will reduce the tensile strength due to the low strength of kenaf fibre [45]. For different types of kenaf fibres, increasing the fibre loading from $10 \%$ to $40 \%$ increased the flexural strength of composites accordingly, whereas further increasing the fibre loading to $50 \%$ decreased the flexural strength due to the saturated mixture of fibre in the polymer matrix. The saturated mixture had decreased the ability of polymer to hold the fibre tightly, thus could not sustain the load applied to the whole structure [46]. The fibre size is also one of the important factors in determining the mechanical properties of composite. It was reported that $30 \%$ kenaf fibre in 20 mesh size had a higher tensile strength of $16 \mathrm{MPa}$ compared to 40 mesh kenaf fibre at 13.6 MPa. A larger surface area of 20 mesh filler was suggested to enhance the surface contact and bonding between fibre and matrix [47].

\section{Low Velocity Impact Properties of Kenaf Composites}

Reaction such as rebounding, penetration and perforation will happen during a low velocity impact event [48]. The damage of the specimen can be analysed through the force against displacement graph. Closed loop graph curve indicated that the impactor rebounded when it hit the surface of the specimen [49]. The damages that happened during the low velocity impact event included the matrix cracking, delamination, fibre failure and penetration [50]. Matrix cracking is the initial stage of damage due to low velocity impact. The number of cracks will increase when a larger external load is applied leading to another failure which is delamination [51]. Delamination was found to be induced by matrix cracking when the high transverse shear stresses at the neighboring impacted matrix surface and later develops into a weak interfacial bond which develops into fibre fracture and fibre pullout $[52,53]$. The phenomena of shear cracking and bending cracking are often characterizations of pine tree damage. Pine tree damage usually exhibits on the stiff-thick composite and reserved pine tree damage exhibits on the flexible-thin composite [54,55]. Perforation is the damage when the impactor completely penetrated the specimen. The opened loop curve in force against displacement graph determined that the specimen experienced penetration by the impactor [49].

Researchers have reported that the highest energy absorbed by kenaf/epoxy composites was of $2.83 \mathrm{~J}$ at $15 \%$ fibre content. Meanwhile, a kenaf polyester composite absorbed the maximum energy of 
$4.53 \mathrm{~J}$ at $25 \%$ fibre content [56]. Kenaf fibre reinforced polyvinyl butyral (PVB) showed an increasing trend of impact strength when the fibre content was increased from $10 \%$ to $20 \%$ and $30 \%$, while the highest impact strength result was achieved at $40 \%$ fibre content. However, the impact energy strength of the composite started decreasing at $50 \%$ and $60 \%$ fibre content [57]. The decreasing trend of the impact strength graph when the fibre content was at $50 \%$ and $60 \%$ also presented in the research on the hybridization of kenaf fibre reinforced recycled polypropylene/polyethelene ( $\mathrm{r}-\mathrm{PP} / \mathrm{PE})$ [58]. Fibre content is an important influencing factor applied not only to kenaf reinforced polymer composites, but also to kenaf hybrid composites. A study showed that the 50:50 fibre ratio in bamboo/kenaf hybrid composites led to the highest impact strength result, which was $45 \mathrm{~J} / \mathrm{m}$, compared to the only kenaf reinforced epoxy composite and to the 30:70 fibre ratio in bamboo-kenaf hybrid composites, which recorded 40.6 and $37.8 \mathrm{~J} / \mathrm{m}$, respectively, for impact strength [59].

In a study, three different fibre arrangements were used to fabricate kenaf/polyester composites, namely, perpendicular, anisotropic and isotropic. Pure polyester was used as a control. The impact strength of the obtained materials was tested on an Izod impact tester. Pure polyester showed the lowest result of impact strength, which is $1.42 \mathrm{~kJ} / \mathrm{m}^{2}$. Meanwhile, the highest impact strength result was recorded for the kenaf/polyester composite with the anisotropic fibre arrangement of $6.68 \mathrm{~kJ} / \mathrm{m}^{2}$ [60]. Fibre size also affects the impact energy absorbed by the composites [60]. A study focusing on kenaf fibre reinforced thermoplastic polyurethane (TPU) composites showed that the impact strength values of the materials prepared with the smallest size of kenaf fibre $(<125 \mu \mathrm{m})$, medium size of kenaf fibre $(125-300 \mu \mathrm{m})$ and the largest size of kenaf fibre $(300-425 \mu \mathrm{m})$ were $2.1,2.76$ and $2.97 \mathrm{~kJ} / \mathrm{m}^{2}$, respectively [61].

Different types of matrix gave different impact strength results for woven kenaf fibre composites. In a previous study, the same type of fibre, namely woven kenaf fibre, and the same impact energy, but different fibre orientations, of $0^{\circ} / 90^{\circ}$ and $45^{\circ} /-45^{\circ}$, have been used to fabricate composites using three different types of matrix, specifically, epoxy, unsaturated polyester, and vinyl ester. Woven kenaf fibre reinforced unsaturated polyester showed the highest energy absorbed for both types of fibre orientation [57].

Kenaf fibre tends to absorb moisture because of its hydrophilic nature. Therefore, chemical treatment is applied to modify the fibre surface by removing the hydroxyl groups and impurities from the fibre [62]. A few chemical treatments can be performed to modify the kenaf fibre surface, such as alkaline treatment, silane treatment and a combination of alkaline and silane treatment [63]. The treatment using $\mathrm{NaOH}$ can be summarised in the chemical equation below [63]:

$$
\text { Fibre-OH }+\mathrm{NaOH}=\text { Fibre }+\mathrm{Na}^{+} \mathrm{O}^{-}+\mathrm{H}_{2} \mathrm{O}+\text { impurities }
$$

The untreated fibre presented low impact strength due to the weak interfacial bond between fibre and matrix. The elimination of the hemicellulose, wax and -OH bonding during the fibre treatment enhanced the bonding between fibre and matrix. Treated kenaf fibre gave a higher impact strength to the composites, compared to the untreated one. This is because the $\mathrm{NaOH}$ solution that had been used in treating kenaf fibre improved the properties of kenaf-reinforced thermoplastic polyurethane composites [64]. Izod impact testing revealed that an untreated kenaf reinforced polyester composite showed the lowest value of impact strength, which was $2.61 \mathrm{~kJ} / \mathrm{m}^{2}$. Two different concentrations of $\mathrm{NaOH}$ solution, of $6 \%$ and $9 \%$, had been used to treat kenaf fibre for $12 \mathrm{~h}$. The impact strength of the composite comprising fibre treated with $6 \% \mathrm{NaOH}$ concentration was $15.77 \mathrm{~kJ} / \mathrm{m}^{2}$, while that of the composite with fibre treated with $9 \% \mathrm{NaOH}$ concentration was $6.92 \mathrm{~kJ} / \mathrm{m}^{2}$ [49]. Kenaf fibre treated with propionic anhydride gave better impact strength results, of $7.7 \mathrm{~kJ} / \mathrm{m}^{2}$, compared to kenaf fibre treated with succinic anhydride and untreated fibre, which recorded 7.3 and $5.4 \mathrm{~kJ} / \mathrm{m}^{2}$, respectively [62]. A previous study compared the impact strength of untreated and treated woven kenaf-banana hybrid composites. The authors concluded that the impact strength of the untreated woven kenaf-banana hybrid composite was $23 \mathrm{~kJ} / \mathrm{m}^{2}$, that of the alkali treated woven kenaf-banana material was $26 \mathrm{~kJ} / \mathrm{m}^{2}$ and that of the material treated with sodium lauryl sulfate (SLS) was $28 \mathrm{~kJ} / \mathrm{m}^{2}$ [65]. The findings 
of reported research studies about the effects of kenaf fibre treatment on the impact strength of the prepared composites are summarised in Table 5. Enzymatic treatment has been also used to modify the surface of fibre. In previous research, kenaf fibre treated with laccase enzyme showed a $26.31 \mathrm{~J} / \mathrm{m}^{2}$ impact strength, while untreated fibre showed a $22.51 \mathrm{~J} / \mathrm{m}^{2}$ impact strength [66].

Table 5. Previous studies on different kenaf fibre treatment.

\begin{tabular}{|c|c|c|c|c|}
\hline Composites & & Parameters & Impact Strength & Ref. \\
\hline \multirow{3}{*}{ Kenaf + polyester } & \multirow{9}{*}{ Chemical treatment } & Untreated & $2.61 \mathrm{~kJ} / \mathrm{m}^{2}$ & \multirow{3}{*}{ [42] } \\
\hline & & Treated with $6 \% \mathrm{NaOH}$ & $15.77 \mathrm{~kJ} / \mathrm{m}^{2}$ & \\
\hline & & Treated with $9 \% \mathrm{NaOH}$ & $6.92 \mathrm{~kJ} / \mathrm{m}^{2}$ & \\
\hline \multirow{3}{*}{ Kenaf + polyester } & & Untreated & $5.4 \mathrm{~kJ} / \mathrm{m}^{2}$ & \multirow{3}{*}{ [62] } \\
\hline & & Propionic anhydride & $7.7 \mathrm{~kJ} / \mathrm{m}^{2}$ & \\
\hline & & Succinic anhydride & $7.3 \mathrm{~kJ} / \mathrm{m}^{2}$ & \\
\hline \multirow{3}{*}{$\begin{array}{c}\text { Kenaf/banana }+ \text { unsaturated } \\
\text { polyester }\end{array}$} & & Untreated & $23 \mathrm{~kJ} / \mathrm{m}^{2}$ & \multirow{3}{*}{ [65] } \\
\hline & & Treated with alkali & $26 \mathrm{~kJ} / \mathrm{m}^{2}$ & \\
\hline & & Treated with sodium lauryl sulfate & $28 \mathrm{~kJ} / \mathrm{m}^{2}$ & \\
\hline \multirow{2}{*}{$\begin{array}{l}\text { Kenaf }+ \text { recycled } \\
\text { polypropylene }\end{array}$} & \multirow{2}{*}{$\begin{array}{l}\text { Enzymatic } \\
\text { treatment }\end{array}$} & Untreated & $22.51 \mathrm{~J} / \mathrm{m}^{2}$ & \multirow{2}{*}{ [66] } \\
\hline & & Treated with laccase enzyme & $26.13 \mathrm{~J} / \mathrm{m}^{2}$ & \\
\hline
\end{tabular}

Hybrid banana/kenaf/banana reinforced epoxy composites were evaluated by using the Charpy test and the maximum impact energy was found to be $12 \mathrm{~J}$. This is the highest impact energy achieved in this study, among other hybrids, such as kenaf/kenaf/kenaf and neem/kenaf/neem composites, which reached values of 4 and $10 \mathrm{~J}$, respectively [65]. The hybridization of kenaf fibre with synthetic fibre such as Kevlar enhanced the impact strength performance of the hybrid composite [67]. In a previous study, the highest impact strength of kenaf/Kevlar hybrid composite that been recorded was $50.1 \mathrm{~kJ} / \mathrm{m}^{2}$ which belonged to the Kevlar/kenaf/Kevlar/kenaf hybrid composite. This study also concluded that the number of fibre layers and fibre sequences became factors that affected the impact properties of the kenaf/Kevlar hybrid [68].

\section{Low Velocity Impact of Glass Composites}

Previous research reported that E-glass composites are more resistant to impact compared to C-glass, specifically, that smaller damage at a higher peak force was found on E-glass composites at the same impact energy level [69]. In terms of weaving pattern, woven E-glass fibre gives better mechanical properties, compared to chopped strand fibre mat. It was reported that woven E-glass fibre has an impact strength of $415 \mathrm{MPa}$, while chopped strand E-glass fibre presented $189 \mathrm{MPa}$ [70].

Fibre content and fibre arrangement affect the impact properties of not only natural fibre composites, but also of glass fibre composites. A study showed that the maximum impact energy absorbed by composites made from one layer of plain-weave glass fibre and two layers of chopped strand glass mats, with $30 \%$ fibre content, was $112.105 \mathrm{~kJ} / \mathrm{m}^{2}$, while that of composites fabricated from two layers of plain-weave glass fibre and one layer of chopped strand glass mat, with $22 \%$ fibre content, was $77.141 \mathrm{~kJ} / \mathrm{m}^{2}$ [70]. Another study reported that a glass wool fibre reinforced epoxy material with a $40 \%$ fibre weight gave the highest impact strength value, which was $0.0862 \mathrm{~J} / \mathrm{m}^{2}$, compared to $30 \%$ and $50 \%$ glass wool fibre weight composites, which reached 0.0652 and $0.0421 \mathrm{~J} / \mathrm{m}^{2}$, respectively [71].

\section{Low Velocity Impact of Kenaf/Glass Hybrid Composites}

The impact strength properties of hybrid composites have been found to be affected by several factors, including volume fraction, fibre matrix adhesion, fibre orientation, fibre length, stress transfer and the thickness of the composites [72]. The reported research findings on kenaf fibre and glass fibre hybrid composites are tabulated in Table 6. 
Table 6. Previous studies on kenaf/glass fibre hybrid composites.

\begin{tabular}{|c|c|c|c|c|}
\hline Kenaf Fibre & Glass Fibre & Matrix & Fabrication Method & Ref. \\
\hline Woven kenaf fiber & Woven E-glass fiber & Epoxy & Hand lay-up & [73] \\
\hline Twisted long kenaf fiber & Glass fiber & Epoxy & Hand lay-up & [74] \\
\hline $\begin{array}{c}\text { Kenaf fiber } \\
\left(\text { direction } 0^{\circ}, 90^{\circ}\right)\end{array}$ & $\begin{array}{l}\text { Glass fiber direction } \\
\left(0^{\circ}, 90^{\circ}\right)\end{array}$ & Epoxy & Hand lay-up & {$[38]$} \\
\hline Twisted kenaf fiber & Woven glass fiber & Epoxy & $\begin{array}{c}\text { Vacuum pump } \\
\text { Compression moulding }\end{array}$ & [75] \\
\hline Kenaf fibre & Woven fibre glass & Polyester & $\begin{array}{l}\text { Hand lay-up } \\
\text { Cold press }\end{array}$ & [76] \\
\hline $\begin{array}{c}\text { Kenaf mat } \\
(20 \mathrm{~cm} \times 20 \mathrm{~cm})\end{array}$ & $\begin{array}{c}\text { Glass fiber } \\
(20 \mathrm{~cm} \times 20 \mathrm{~cm})\end{array}$ & Unsaturated polyester & $\begin{array}{l}\text { Hand lay-up } \\
\text { Compression }\end{array}$ & [77] \\
\hline Kenaf fibre & Glass fibre & Unsaturated polyester & Cold pressure hand lay-up & [78] \\
\hline Non- woven kenaf mat & E-glass fibre & Polypropylene & Compression moulding & [79] \\
\hline
\end{tabular}

The composite fabricated with a $90^{\circ}$ kenaf/glass fibre orientation had a higher impact strength compared to the one with a $0^{\circ}$ fibre orientation, namely, of 6.66 and $6 \mathrm{~J}$, respectively. Due to its better impact strength, it was suggested that the hybrid composite can be used in structural applications [38]. Previous work reported that twisted neem/kenaf/neem composites, with a fibre orientation of $90^{\circ} / 45^{\circ} / 90^{\circ}$, embedded with glass fibre at the outermost top and bottom layers, recorded the maximum impact strength of $12.2 \mathrm{~J}$, which was higher than the values achieved by neem $/ \mathrm{kenaf} /$ neem composites with fibre orientations of $0^{\circ} / 0^{\circ} / 0^{\circ}$ and $0^{\circ} / 90^{\circ} / 0^{\circ}(11.23$ and $11.64 \mathrm{~J}$, respectively) [65].

At $9 \mathrm{~J}$ of impact energy, kenaf/glass hybrid composites with $3 \mathrm{~mm}$ thickness showed a major crack length of $52.92 \mathrm{~mm}$, while kenaf/epoxy composites reached $100.61 \mathrm{~mm}$ for major crack length. The smaller damage on the kenaf/glass hybrid composites indicated that embedded woven glass hybridised with kenaf led to stronger impact resistance. Meanwhile, the glass/epoxy composite showed $16.02 \mathrm{~mm}$ radius of damage [79]. In another study, $75 \%$ glass fibre and $25 \%$ kenaf fibre composites showed almost similar results to those achieved for $100 \%$ glass fibre. The hybrid composites were selected to undergo low velocity testing. The hybrid composite with 10 layers of glass and kenaf fibre could absorb an impact energy of up to $40 \mathrm{~J}$ [49].

\section{Conclusions}

Kenaf fibre has great potential in automotive application as a reinforcement fibre, since it is light in weight, eco-friendly, low-cost and has good mechanical properties. Reinforcing kenaf fibre with glass fibre is one of the methods to enhance kenaf fibre composites because glass fibre has better mechanical and impact properties than kenaf fibre. There are several factors that affect the mechanical and impact properties of the kenaf/glass hybrid composites. Previous studies show that the optimum fibre content and fibre orientation were between $30 \%$ and $40 \%$ and $90^{\circ}$, where it can resist a higher impact strength and have better mechanical properties. Fibre surface modification also helps to improve the properties of kenaf/glass hybrid composites. The number of layers and the thickness of the composite also influences its mechanical and impact strength properties. From the review conducted, it can be suggested that kenaf/glass hybrid composites have higher tensile strength up to $85 \mathrm{MPa}$ compared to kenaf composites. Other than that, kenaf/glass hybrid composite can also withstand low velocity impact energy up to $12 \mathrm{~J}$. The mechanical and impact properties of kenaf/glass hybrid composites discussed in this manuscript show its potential for use in automotive applications. It was also found that limited studies were done on the mechanical and impact properties of the kenaf/glass hybrid composites, and further investigations were needed to maximise the potential of kenaf/glass hybrid composites.

Acknowledgments: The authors would like to thank Universiti Putra Malaysia for the financial support through the Fundamental Research Grant Scheme FGRS/1/2019/STG07/UPM/02/2 (5540320). The authors would like to thank the Department of Aerospace Engineering, Faculty of Engineering, Universiti Putra Malaysia and Laboratory of Biocomposite Technology, Institute of Tropical Forestry and Forest Product (INTROP), Universiti Putra Malaysia (HICOE) for the close collaboration in this research.

Conflicts of Interest: The authors declare no conflict of interest. 


\section{References}

1. Zakikhani, P.; Zahari, R.; Sultan, M.T.; Majid, D.L. Thermal degradation of four bamboo species. BioResources 2016, 11, 414-425. [CrossRef]

2. Mohammed, L.; Ansari, M.N.; Pua, G.; Jawaid, M.; Islam, M.S. A review on natural fiber reinforced polymer composite and its applications. Int. J. Polym. Sci. 2015, 2015, 243947. [CrossRef]

3. Peças, P.; Carvalho, H.; Salman, H.; Leite, M. Natural fibre composites and their applications: A review. J. Compos. Sci. 2018, 2, 66. [CrossRef]

4. Khan, T.; Hameed Sultan, M.T.; Ariffin, A.H. The challenges of natural fiber in manufacturing, material selection, and technology application: A review. J. Reinf. Plast. Compos. 2018, 37, 770-779. [CrossRef]

5. Chee, S.S.; Jawaid, M.; Sultan, M.T.; Alothman, O.Y.; Abdullah, L.C. Thermomechanical and dynamic mechanical properties of bamboo/woven kenaf mat reinforced epoxy hybrid composites. Compos. Part B Eng. 2019, 163, 165-174. [CrossRef]

6. Venkateshwaran, N.; Elayaperumal, A.; Sathiya, G.K. Prediction of tensile properties of hybrid-natural fiber composites. Compos. Part B Eng. 2012, 43, 793-796. [CrossRef]

7. Sood, M.; Dwivedi, G. Effect of fiber treatment on flexural properties of natural fiber reinforced composites: A review. Egypt. J. Pet. 2018, 27, 775-783. [CrossRef]

8. Sanjay, M.R.; Yogesha, B. Studies on hybridization effect of jute/kenaf/E-glass woven fabric epoxy composites for potential applications: Effect of laminate stacking sequences. J. Ind. Text. 2018, 47, 1830-1848. [CrossRef]

9. Gangil, B.; Kumar, S. Comparative evaluation on mechanical properties of jute/bamboo-glass hybrid reinforced polyester composites. Asian J. Sci. Technol. 2017, 8, 5190-5194.

10. Panthapulakkal, S.; Sain, M. Injection-molded short hemp fiber/glass fiber-reinforced polypropylene hybrid composites-Mechanical, water absorption and thermal properties. J. Appl. Polym. Sci. 2007, 103, 2432-2441. [CrossRef]

11. Zuhudi, N.Z.; Lin, R.J.; Jayaraman, K. Flammability, thermal and dynamic mechanical properties of bamboo-glass hybrid composites. J. Thermoplast. Compos. Mater. 2016, 29, 1210-1228. [CrossRef]

12. Safri, S.N.; Sultan, M.T.; Jawaid, M.; Majid, M.A. Analysis of dynamic mechanical, low-velocity impact and compression after impact behaviour of benzoyl treated sugar palm/glass/epoxy composites. Compos. Struct. 2019, 226, 111308. [CrossRef]

13. Satya, P.; Karan, M.; Kar, C.S.; Mahapatra, A.K.; Mahapatra, B.S. Assessment of molecular diversity and evolutionary relationship of kenaf (Hibiscus cannabinus L.), roselle (H. sabdariffa L.) and their wild relatives. Plant Syst. Evol. 2013, 299, 619-629. [CrossRef]

14. Devadas, A.; Nirmal, U.; Hossen, J. Investigation into mechanical \& tribological performance of kenaf fibre particle reinforced composite. Cogent Eng. 2018, 5, 1479210.

15. Mohd, H.; Arifin, A.; Nasima, J.; Hazandy, A.H.; Khalil, A. Journey of kenaf in Malaysia: A review. Sci. Res. Essays 2014, 9, 458-470. [CrossRef]

16. Ayadi, R.; Hanana, M.; Mzid, R.; Hamrouni, L.; Khouja, M.L.; Salhi Hanachi, A. Hibiscus cannabinus L.-Kenaf: A review paper. J. Nat. Fibers 2017, 14, 466-484.

17. Akil, H.; Omar, M.F.; Mazuki, A.A.; Safiee, S.Z.; Ishak, Z.M.; Bakar, A.A. Kenaf fiber reinforced composites: A review. Mater. Des. 2011, 32, 4107-4121. [CrossRef]

18. Kumar, R.; Hashmi, S.A.; Nimanpure, S.; Naik, A. Enhanced dynamic mechanical properties of kenaf epoxy composites. Adv. Mater. Proceeding 2017, 749-757. [CrossRef]

19. Jeyanthi, S.; Rani, J.J. Improving mechanical properties by kenaf natural long fiber reinforced composite for automotive structures. J. Appl. Sci. Eng. 2012, 15, 275-280.

20. Saba, N.; Paridah, M.T.; Jawaid, M. Mechanical properties of kenaf fibre reinforced polymer composite: A review. Constr. Build. Mater. 2015, 76, 87-96. [CrossRef]

21. Adole, A.M.; Yatim, J.M.; Ramli, S.A.; Othman, A.; Mizal, N.A. Kenaf Fibre and Its Bio-Based Composites: A Conspectus. Pertanika J. Sci. Technol. 2019, 27, 297-329.

22. Juliana, A.H.; Paridah, M.T.; Rahim, S.; Nor Azowa, I.; Anwar, U.M. Effect of adhesion and properties of kenaf (Hibiscus cannabinus L.) stem in particleboard performance. J. Adhes. Sci. Technol. 2014, 28, 546-560. [CrossRef] 
23. Kian, L.K.; Saba, N.; Jawaid, M.; Sultan, M.T. A review on processing techniques of bast fibers nanocellulose and its polylactic acid (PLA) nanocomposites. Int. J. Biol. Macromol. 2019, 121, 1314-1328. [CrossRef] [PubMed]

24. Paridah, M.T.; Basher, A.B.; SaifulAzry, S.; Ahmed, Z. Retting process of some bast plant fibres and its effect on fibre quality: A review. BioResources 2011, 6, 5260-5281.

25. Sisti, L.; Totaro, G.; Vannini, M.; Celli, A. Retting process as a pretreatment of natural fibers for the development of polymer composites. In Lignocellulosic Composite Materials; Springer International Publishing: Cham, Switzerland, 2018; pp. 97-135.

26. Bacci, L.; Di Lonardo, S.; Albanese, L.; Mastromei, G.; Perito, B. Effect of different extraction methods on fiber quality of nettle (Urtica dioica L.). Text. Res. J. 2011, 81, 827-837. [CrossRef]

27. Vetter, R.E.; Ribeiro, R.A.; Ribeiro, M.G.; Miranda, I.P. Studies on drying of imperial bamboo. Eur. J. Wood Wood Prod. 2015, 73, 411-414. [CrossRef]

28. Fan, M.; Weclawski, B. Long natural fibre composites. In Advanced High Strength Natural Fibre Composites in Construction; Woodhead Publishing: Cambriadge, UK, 2017; pp. 141-177.

29. Ayorinde, A.T.; Makanjuola, G.A.; Aluko, O.B.; Owolarafe, O.K.; Sanni, L.A. Performance evaluation of a kenaf decorticator. Agric. Eng. Int. CIGR J. 2019, 21, 192-202.

30. Gao, S.; Han, G.; Jiang, W.; Zhang, Y.; Zhang, X. Steam explosion and alkali-oxygen combined effect for degumming of kenaf fiber. BioResources 2015, 10, 5476-5488. [CrossRef]

31. Wong, L.Y.; Saad, W.Z.; Mohamad, R.; Tahir, P.M. Efficacy of Aspergillus fumigatus R6 Pectinase in Enzymatic Retting of Kenaf. BioResources 2016, 11, 10030-10041. [CrossRef]

32. Mohd Nurazzi, N.; Khalina, A.; Sapuan, S.M.; Dayang Laila, A.H.; Rahmah, M.; Hanafee, Z. A Review: Fibres, Polymer Matrices and Composites. Pertanika J. Sci. Technol. 2017, 25, 1085-1102.

33. Sharba, M.J.; Leman, Z.; Sultan, M.T.; Ishak, M.R.; Hanim, M.A. Partial replacement of glass fiber by woven kenaf in hybrid composites and its effect on monotonic and fatigue properties. BioResources 2016, 11, 2665-2683. [CrossRef]

34. Prince Engineering. 2018. Available online: https://www.build-on-prince.com/ (accessed on 12 July 2019).

35. Shah, A.U.; Sultan, M.T.; Jawaid, M.; Cardona, F.; Talib, A.R. A review on the tensile properties of bamboo fiber reinforced polymer composites. BioResources 2016, 11, 10654-10676.

36. Landesmann, A.; Seruti, C.A.; Batista, E.D. Mechanical properties of glass fiber reinforced polymers members for structural applications. Mater. Res. 2015, 18, 1372-1383. [CrossRef]

37. Gibhardt, D.; Doblies, A.; Meyer, L.; Fiedler, B. Effects of hygrothermal ageing on the interphase, fatigue, and mechanical properties of glass fibre reinforced epoxy. Fibers 2019, 7, 55. [CrossRef]

38. Ramesh, M.; Nijanthan, S. Mechanical property analysis of kenaf-glass fibre reinforced polymer composites using finite element analysis. Bull. Mater. Sci. 2016, 39, 147-157. [CrossRef]

39. Sapiai, N.; Jumahat, A.; Mahmud, J. Flexural and tensile properties of kenaf/glass fibres hybrid composites filled with carbon nanotubes. J. Teknol. 2015, 76, 115-120. [CrossRef]

40. Salleh, Z.; Berhan, M.N.; Hyie, K.M.; Isaac, D.H. Cold-pressed kenaf and fibreglass hybrid composites laminates: Effect of fibre types. World Acad. Sci. Eng. Technol. Int. Sci. Index 2012, 71, 11.

41. Amel, B.A.; Paridah, M.T.; Sudin, R.; Anwar, U.M.; Hussein, A.S. Effect of fiber extraction methods on some properties of kenaf bast fiber. Ind. Crop. Prod. 2013, 46, 117-123. [CrossRef]

42. Yuhazri, M.Y.; Phongsakorn, P.T.; Haeryip Sihombing, I.P.; Jeefferie, A.R.; Puvanasvaran, A.P.; Kamarul, A.M.; Kannan, R. Mechanical properties of kenaf/polyester composites. Int. J. Eng. Technol. 2011, 11, 127-131.

43. Bakar, N.H.; Hyie, K.M.; Jumahat, A.; Latip, E.N.; Kalam, A.N.; Salleh, Z. Influence of Different Matrices on The Tensile and Impact Properties of Treated Kenaf Composites. Adv. Mater. Res. 2016, 1133, 136-140. [CrossRef]

44. Bakar, N.H.; Hyie, K.M.; Mohamed, A.F.; Salleh, Z.; Kalam, A. Kenaf fibre composites using thermoset epoxy and polyester polymer resins: Energy absorbed versus tensile properties. Mater. Res. Innov. 2014, 18, 505-509. [CrossRef]

45. Salman, S.D.; Leman, Z.; Sultan, M.T.; Ishak, M.R.; Cardona, F. The effects of orientation on the mechanical and morphological properties of woven kenaf-reinforced poly vinyl butyral film. BioResources 2016, 11, 1176-1188. [CrossRef] 
46. Salman, S.D.; Leman, Z.; Sultan, M.T.; Ishak, M.R.; Cardona, F. Influence of fiber content on mechanical and morphological properties of woven kenaf reinforced PVB film produced using a hot press technique. Int. J. Polym. Sci. 2016. [CrossRef]

47. Mohd Radzuan, N.A.; Ismail, N.F.; Radzi, F.M.; Khairul, M.; Razak, Z.B.; Tharizi, I.B.; Sulong, A.B.; Che Haron, C.H.; Muhamad, N. Kenaf Composites for Automotive Components: Enhancement in Machinability and Moldability. Polymers 2019, 11, 1707. [CrossRef] [PubMed]

48. Pandian, A.; Sultan, M.T.H.; Marimuthu, U.; Shah, A.U.M. Low Velocity Impact Studies on Fibre-Reinforced Polymer Composites and Their Hybrids-Review In Encyclopedia of Renewable and Sustainable Materials; Elsevier: Oxford, UK, 2019; pp. 1-12.

49. Ismail, M.F.; Sultan, M.T.; Hamdan, A.; Shah, A.U.; Jawaid, M. Low velocity impact behaviour and post-impact characteristics of kenaf/glass hybrid composites with various weight ratios. J. Mater. Res. Technol. 2019, 8, 2662-2673. [CrossRef]

50. Razali, N.; Sultan, M.T.; Mustapha, F.; Yidris, N.; Ishak, M.R. Impact damage on composite structures-A review. Int. J. Eng. Sci. 2014, 3, 8-20.

51. Maimi, P.; Rodríguez, H.; Blanco, N.; Mayugo, J.A. Numerical modeling of matrix cracking and intralaminar failure in advanced composite materials. In Numerical Modelling of Failure in Advanced Composite Materials; Woodhead Publishing: Cambriadge, UK, 2015; pp. 175-192.

52. Boria, S.; Scattina, A.; Belingardi, G. Impact behavior of a fully thermoplastic composite. Compos. Struct. 2017, 167, 63-75. [CrossRef]

53. Tan, R.; Xu, J.; Sun, W.; Liu, Z.; Guan, Z.; Guo, X. Relationship Between Matrix Cracking and Delamination in CFRP Cross-Ply Laminates Subjected to Low Velocity Impact. Materials 2019, 12, 3990. [CrossRef]

54. Sarasini, F.; Tirillò, J.; D’Altilia, S.; Valente, T.; Santulli, C.; Touchard, F.; Chocinski-Arnault, L.; Mellier, D.; Lampani, L.; Gaudenzi, P. Damage tolerance of carbon/flax hybrid composites subjected to low velocity impact. Compos. Part B Eng. 2016, 91, 144-153. [CrossRef]

55. Sultan, M.T.; Worden, K.; Staszewski, W.J.; Pierce, S.G.; Dulieu-Barton, J.M.; Hodzic, A. Impact damage detection and quantification in CFRP laminates; a precursor to machine learning. In Proceedings of the 7th International Workshop on Structural Health Monitoring (IWSHM 2009), Stanford, CA, USA, 9-11 September 2009; pp. 1528-1537.

56. Wan Busu, W.N.; Anuar, H.; Ahmad, S.H.; Rasid, R.; Jamal, N.A. The mechanical and physical properties of thermoplastic natural rubber hybrid composites reinforced with Hibiscus cannabinus, L and short glass fiber. Polym. Plast. Technol. Eng. 2010, 49, 1315-1322. [CrossRef]

57. Salman, S.D.; Sharba, M.J.; Leman, Z.; Sultan, M.T.; Ishak, M.R.; Cardona, F. Physical, mechanical, and morphological properties of woven kenaf/polymer composites produced using a vacuum infusion technique. Int. J. Polym. Sci. 2015, 2015, 894565. [CrossRef] [PubMed]

58. Taufiq, M.J.; Mansor, M.R.; Mustafa, Z. Characterisation of wood plastic composite manufactured from kenaf fibre reinforced recycled-unused plastic blend. Compos. Struct. 2018, 189, 510-515. [CrossRef]

59. Ismail, A.S.; Jawaid, M.; Sultan, M.T.; Hassan, A. Physical and Mechanical Properties of Woven Kenaf/Bamboo Fiber Mat Reinforced Epoxy Hybrid Composites. BioResources 2019, 14, 1390-1404.

60. Yong, C.K.; Ching, Y.C.; Chuah, C.H.; Liou, N.S. Effect of fiber orientation on mechanical properties of kenaf-reinforced polymer composite. BioResources 2015, 10, 2597-2608. [CrossRef]

61. El-Shekeil, Y.A.; Salit, M.S.; Abdan, K.; Zainudin, E.S. Development of a new kenaf bast fiber-reinforced thermoplastic polyurethane composite. BioResources 2011, 6, 4662-4672.

62. Khalil, H.A.; Suraya, N.L.; Atiqah, N.; Jawaid, M.; Hassan, A. Mechanical and thermal properties of chemical treated kenaf fibres reinforced polyester composites. J. Compos. Mater. 2013, 47, 3343-3350. [CrossRef]

63. Hamidon, M.H.; Sultan, M.T.; Ariffin, A.H.; Shah, A.U. Effects of fibre treatment on mechanical properties of kenaf fibre reinforced composites: A review. J. Mater. Res. Technol. 2019, 8, 3327-3337. [CrossRef]

64. Noor Azammi, A.M.; Sapuan, S.M.; Ishak, M.R.; Sultan, M.T. Mechanical properties of kenaf fiber thermoplastic polyurethane-natural rubber composites. Polimery 2018, 63, 524-530. [CrossRef]

65. Alavudeen, A.; Rajini, N.; Karthikeyan, S.; Thiruchitrambalam, M.; Venkateshwaren, N. Mechanical properties of banana/kenaf fiber-reinforced hybrid polyester composites: Effect of woven fabric and random orientation. Mater. Des. 2015, 66, 246-257. [CrossRef]

66. Islam, M.R.; Beg, M.D.; Gupta, A. Characterization of laccase-treated kenaf fibre reinforced recycled polypropylene composites. BioResources 2013, 8, 3753-3770. [CrossRef] 
67. Salman, S.D.; Leman, Z.; Sultan, M.T.; Ishak, M.R.; Cardona, F. Kenaf/synthetic and Kevlar®/cellulosic fiber-reinforced hybrid composites: A review. BioResources 2015, 10, 8580-8603. [CrossRef]

68. Yahaya, R.; Sapuan, S.M.; Jawaid, M.; Leman, Z.; Zainudin, E.S. Effect of layering sequence and chemical treatment on the mechanical properties of woven kenaf-aramid hybrid laminated composites. Mater. Des. 2015, 67, 173-179. [CrossRef]

69. Mostafa, N.H.; Ismarrubie, Z.N.; Sapuan, S.M.; Sultan, M.T. Effect of equi-biaxially fabric prestressing on the tensile performance of woven E-glass/polyester reinforced composites. J. Reinf. Plast. Compos. 2016, 35, 1093-1103. [CrossRef]

70. Heckadka, S.S.; Nayak, S.Y.; Narang, K.; Vardhan Pant, K. Chopped strand/plain weave E-glass as reinforcement in vacuum bagged epoxy composites. J. Mater. 2015, 2015, 957043. [CrossRef]

71. Thirukumaran, M.; Kannan, L.V.; Sankar, I. Study on mechanical properties of glass wool/epoxy reinforced composite. Int. J. Comput. Aided Eng. Technol. 2018, 10, 15-25. [CrossRef]

72. Salman, S.D.; Leman, Z.; Sultan, M.T.; Ishak, M.R.; Cardona, F. Effect of kenaf fibers on trauma penetration depth and ballistic impact resistance for laminated composites. Text. Res. J. 2017, 87, 2051-2065. [CrossRef]

73. Davoodi, M.M.; Sapuan, S.M.; Ahmad, D.; Aidy, A.; Khalina, A.; Jonoobi, M. Effect of polybutylene terephthalate (PBT) on impact property improvement of hybrid kenaf/glass epoxy composite. Mater. Lett. 2012, 67, 5-7. [CrossRef]

74. Mohammed, M.; Rozyanty, A.R.; Beta, B.O.; Adam, T.; Osman, A.F.; Salem, I.A.; Dahham, O.S.; Al-Samarrai, M.N.; Mohammed, A.M. Influence of weathering effect in natural environment on thermal properties hybrid kenaf blast/glass fibre and unsaturated polyester composite. J. Phys. Conf. Ser. 2017, 908, 012004. [CrossRef]

75. Ramnath, B.V.; Rajesh, S.; Elanchezhian, C.; Shankar, A.S.; Pandian, S.P.; Vickneshwaran, S.; Rajan, R.S. Investigation on mechanical behaviour of twisted natural fiber hybrid composite fabricated by vacuum assisted compression molding technique. Fibers Polym. 2016, 17, 80-87. [CrossRef]

76. Jamal, S.K.; Hassan, S.A.; Wong, K.J.; Yahya, M.Y. Flexural and interlaminar shear study of hybrid woven kenaf/recycled GFRP (rGFRP) composites subjected to bending load. Int. J. Adv. Appl. Sci. 2017, 4, 45-50. [CrossRef]

77. Elanchezhian, C.; Ramnath, B.V.; Kaosik, R.; Nellaiappan, T.K.; Santhosh Kumar, K.; Kavirajan, P.; Sughan, M.U. Evaluation of Mechanical Properties of Kenaf Based Hybrid Composite for Automotive Components Replacement. ARPN J. Eng. Appl. Sci. 2006, 10, 5518-5523.

78. Asumani, O.M.; Reid, R.G.; Paskaramoorthy, R. The effects of alkali-silane treatment on the tensile and flexural properties of short fibre non-woven kenaf reinforced polypropylene composites. Compos. Part A: Appl. Sci. Manuf. 2012, 43, 1431-1440. [CrossRef]

79. Majid, D.L.; Jamal, Q.M.; Manan, N.H. Low-velocity impact performance of glass fiber, kenaf fiber, and hybrid glass/kenaf fiber reinforced epoxy composite laminates. BioResources 2018, 13, 8839-8852. [CrossRef] 